\title{
Pictorial Metaplan as a Teaching aid to Improve Speaking Skills in Junior High School Students
}

\author{
Deswandito Dwi Saptanto ${ }^{1}$ \\ dittoissublime@gmail.com \\ Tri Arie Bowo ${ }^{2}$ \\ arie622@gmail.com \\ Ratih Laily Nurjanah ${ }^{3}$ \\ ratih.laily@gmail.com \\ 1,2,3 Department of English Literature, Ngudi Waluyo University
}

\begin{abstract}
This study focuses on improving students' abilities in learning English with the support of Pictorial Metaplan as a teaching aid. The use of this Metaplan aims to improve speaking skills in formal and non-formal contexts. This pictorial Metaplan is a realia in the form of an illustrated carpet with a theme Getting Direction. Pictorial Metaplan focuses on the topic Getting Direction and applied directly to 15 students in the 8th grade of junior high school. The implementation of the use of the Pictorial Metaplan begins with distributing questionnaires and implementing Pre- Test and Post-Test, then direct implementation of using Pictorial Metaplan combined with Total Physical Response (TPR) method. The treatment for students was carried out by dividing two class groups, the control group, and the experimental group. The control group used conventional methods, without using learning aids, while the second group used the Pictorial Metaplan as a teaching aid. Based on the results of Pre-Test and Post-Test show an increase in the results of the values before and after implementing the Pictorial Metaplan. Thus it can be concluded that learning in the experimental group using Pictorial Metaplan is more effective than learning using conventional methods.
\end{abstract}

Keywords: Pictorial Metaplan, Teaching aid, Total Physical Response (TPR)

\section{INTRODUCTION}

Learning English as a second language for young learners certainly provides many advantages namely the ability to speak English properly and correctly. Uysal and Yavuz, (2015) states that learning English from an early age will certainly get optimal results in increasing a person's ability to learn English. The learning process should use various methods and materials according to their needs.

Anggani and Bharati (2010) states that recently learning and teaching process using English as the medium of communication becomes a trend in Indonesia. A school that conducts this method must have professional teachers that are not only good at teaching but also good at preparing the administration stuff (lesson plan, material, media, and documents).
Hapsari (2020) also states that teachers hold the key role of the success in teaching and learning in the class. The teacher must be able to develop and create interesting materials, teaching aid, and also good class management. These will affect the student's motivation, so they can enjoy studying the material with their teacher.

The use of a teaching aid can act as a medium of assistance in teaching English to become a more interactive and fun subject. This interactive learning provides opportunities for students to take part and interact directly with the help of learning aids. This pictorial Metaplan application can facilitate the interactive English learning process.

The problems that appear in learning English are the lack of appropriate materials and teaching aid that able to facilitate students in 
learning English interactively. Lack of time and the lack of direct interaction with one another using English in the classroom is what causes students' abilities to not develop optimally. The students' lack of ability will cause new problems, namely fears and worries in using English in non-formal and formal contexts.

This problem must be resolved immediately, by directly applying the use of the Pictorial Metaplan as a teaching aid combined with the roleplay method. Clapper (2010) argues that the use of the role-play method provides many benefits for students who are learning material. The role-play method can spur a student to think critically in solving problems. This study aims to see the improvement of students in learning English, especially in speaking competence. Pictorial Metaplan will be used as a teaching aid to improve speaking skills.

The novelty or state of the art from this research is to create a Pictorial Metaplan product in the form of a carpet with pictures integrated into English subjects in 8th grade of Junior High School students. The pictorial Metaplan has the theme Getting Direction which has the aim of creating an interactive and thematic learning atmosphere in the class. This Pictorial Metaplan will be applied to the students which are carried out with the Total Physical Response (TPR) method to obtain a valid result of an increase in the value of skills obtained before and after the application of this Pictorial Metaplan.

This Pictorial Metaplan consists of a pictorial carpet, a list of street names in three major cities in the world (Semarang, New York, London), a package of building names, and a carpet containing questions that will be used to ask directions. The direct learning process to communicate using English will be created very effectively, interactive and communicative because the use of Pictorial Metaplan must be done by two people in one team. The final result that is expected from the direct application of the use of Pictorial Metaplan can improve students' skills in learning English, especially speaking skills.

\section{Speaking Ability}

The ability to speak English well is something everyone needs, this is because English plays an important role in the success of communicating with foreign parties as well as a major success factor in the sphere of education, employment, business, international relations, and technological developments.

English skills, especially in speaking and vocabulary is the main thing because these two things are the basis for a person to master and communicate well in English. As we know, English is an international language that must be mastered.

By referring to the explanation above, it can be seen that speaking has a major role in various aspects, A person's success in communicating means that the message is conveyed well and effectively. However, the basic ability to speak fluently in English is certainly supported by the large number of vocabulary we have, the more vocabulary we master, the smoother and more interesting the sentences we create. Speaking skills is the key to success to gain profit and success in the communication process.

Khan and Ali (2010) find a phenomenon that has been experienced by students, namely the limited time and opportunities for them to make presentations and speak in English in class. Refer to this point then Derakhshan et al. (2016) state that speaking learning should focus on direct practical activities using interesting materials so that oral activities are created such as imitation, responsiveness, intensive extensive performance, transactional dialogue, and interpersonal dialogue to improve their speaking abilities. People who learn English as a foreign language can improve their speaking skills with the help of media such as role-plays, videos, flashcards, and graphs. Interactive learning media is very suitable to be used as a learning aid in the scope of speaking competence.

\section{Role-play}


Increasing the ability to speak in English certainly requires an appropriate method for students, so they have enough time and opportunity to interact directly with the material provided by the teacher. The role-play method is a suitable method for implementing interactive English learning. Liu \& Ding (2009) stated that the role-play method is a very effective technique to be able to create an atmosphere of teaching and learning in the classroom, increase enthusiasm for learning, try to interact verbally with the existing material, and create great new words. The use of the role-play method must be supported by interesting and new material, the teacher as a facilitator and students as a participant, the teacher must synergize with the material and immediately correct mistakes when students do the direct practice.

\section{Total Physical Response}

Total Physical Response (TPR) is a method suitable for the interactive learning process. Putri (2016) expressed the opinion that TPR is a decent method for young learners. It can help young learners to memorize some commands or some vocabularies easily through the use of their physical movement. The students will not only learnable but also interesting and enjoyable.

In the application of this TPR, a teacher must be prepared with several things, namely: as a teacher, as a role model who functions as an action supervisor until students are ready to imitate what the teacher says and does. This method is great for improving students' listening and speaking skills. Sano (1986) stated that the TPR method is very effective to be applied in learning English for beginners. Because by using the TPR method, the learning process becomes more active, interactive, and effective. The application of this TPR can make students more creative and communicative in learning the material.

\section{Pictorial Metaplan as a Teaching Aid}

The use of Pictorial Metaplan as a teaching aid media can increase students' interest in learning English more dynamically and creatively. Asemota (2015) states that teaching aids help the learning process on both sides, namely helping the teaching process carried out by the teacher and also helping students in learning material using interactive methods. The use of media can be a medium in the scope of learning and offer more interesting learning concepts. The use of this learning media can be right on target, and practical. Learning media can facilitate students to interact with the object directly by seeing, hearing, and feeling the material provided by the teacher. The learning media stimulates the users' thinking and creativity to be applied in direct practice in the classroom.

Pictorial Metaplan can develop creative ideas and make them easy to convey. The use of Metaplan can facilitate users in finding and determining their ideas from those that are still in a general context to those that are more focused and specific. Maisiska (2014) through the results of her research explains that learning using Metaplan can help students to be more creative, communicative, and interactive. The use of Metaplan in learning can also make users' ideas more structured and directed.

Ramshaw (1989) also states that the use of Metaplan is very effective when it is used as a medium in problem-solving discussions, planning a project target, and also for reviewing the results of achievements that have been made by an organization or company in a project.

Croasdell et al. (2003) suggest that the concept map is generally shaped like a spider web (as the main concept) and is divided and connected to various topic points. The use of Pictorial Metaplan is a modified form of an existing concept map of ideas/thoughts. This pictorial Metaplan is a form of thematic concept, namely in the form of a city map complete with buildings and street names. The position of the building and the name of the street can be moved according to the needs and desires of the user.

Ovchinnikova et al. (2015) have succeeded in using Metaplan as a medium of teaching and learning to improve vocabulary and speaking skills in English for students. Based on some of the researches above, it can be concluded that the teaching and learning media in the form of a Pictorial Metaplan can be integrated and used to 
improve speaking competence with interactive teaching methods.

\section{METHODOLOGY}

This research uses a quantitative method with a quasi group design.

\section{Participants/Samples/Research Subjects}

The subjects of this study were students of 8th grade at Sekolah Menengah Pertama Negeri 3 Ungaran as total sampling which was divided into two types of treatment, namely treatment using conventional method and treatment with role-play method using Pictorial Metaplan as teaching aid. The results of this study were to measure whether the Pictorial Metaplan media could improve the speaking competence of the 8th grade of junior high school students.

\section{Research Steps}

Figure 1

The Picture of a Map to be Given in the Pre-Test and Post-Test

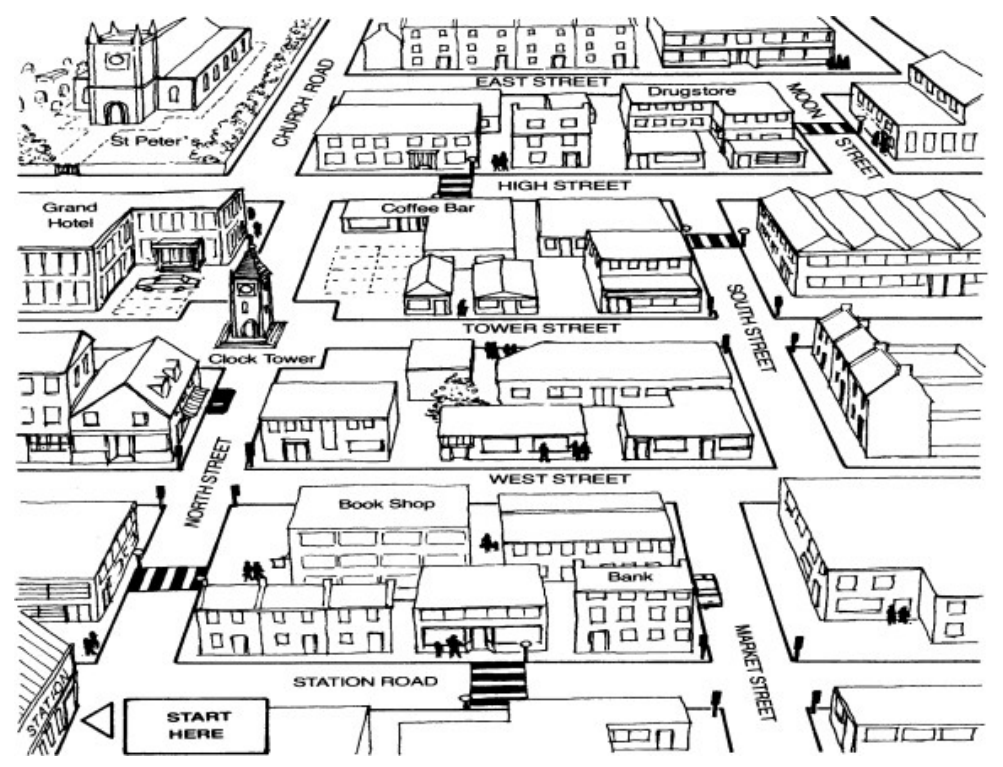

The next step was the treatment stage for the research subject, by dividing all students of 8th grade of junior high school at Sekolah Menengah Pertama Negeri 3 Ungaran into two groups, namely: the control group and the experimental group. The implementation of English learning with the theme Getting Direction was applied to
This study uses a quantitative method with a quasigroup design, according to $\mathrm{Wu} \&$ Little (2011), Quantitative research methods encompass three broad categories: design, measurement, and analysis issues.

Maciejewski (2020) states that Quasiexperiments are similar to randomized controlled trials in many respects, but there are many challenges in designing and conducting a quasiexperiment when internal validity threats are introduced from the absence of randomization. This research created a product of pictorial Metaplan with a city map theme. The quantitative method using paired sample test and independent-sample test were used to calculate this efficiency of the product when it is applied to the users. The following are the steps carried out in the study: The pre-test was carried out to all research subjects using image media with the theme 'Show Me The Direction', the following image is the representation of the material. the research subject. Learning 'direction' was applied with the conventional learning method in the control group and on the other hand, learning 'direction' was applied in the experimental group class using the Pictorial Metaplan as a teaching aid. After being treated three times, the next step was to carry out a Post-Test to the two groups using the 
same question material as the Pre-Test question material. The final step of this research activity was to calculate the results obtained using statistics. The results of this score will show whether the Pictorial Metaplan media is effective in improving the speaking skills of the 8th grade of junior high school students.

\section{RESULT AND DISCUSSION}

The research entitled 'Pictorial Metaplan as a Teaching Aid to Improve Speaking Skills in Junior High School Students' includes several stages, while these stages are as follows:

\section{Implementation of the Pre-Test}

This research begins with the implementation of the Pre-Test given to 30 junior high school students at Sekolah Menengah Pertama Negeri 3 Ungaran.

\section{Pre-Test Stage}

The research subjects were 30 students who followed the Pre-Test stage by applying pictorial questions with the theme Getting Direction.
During the pre-test, 8th-grade students made group presentations. Each group consists of two people, one person will be so

meone who asks about the direction and name of the road to the place you want to go to, while the other person will show you the direction and street names according to the picture problem.

\section{Stage of Assessment and Collection of Pre- Test Results}

In the pre-test, the author made an assessment based on the speaking competency rubric. The rubric aspects consist of fluency, pronunciation, accuracy, clarity, and performance skill.

\section{Treatment Stage}

The treatment stage is the application of learning by carrying out two different learning designs and running simultaneously. Treatment was carried out three times in these two groups (control group and experimental group).

Figure 2

Pictorial Metaplan Image in the Form of a Pictorial Carpet Which is Used by Placing it on the Floor and Then Putting the Names of the Streets and Buildings

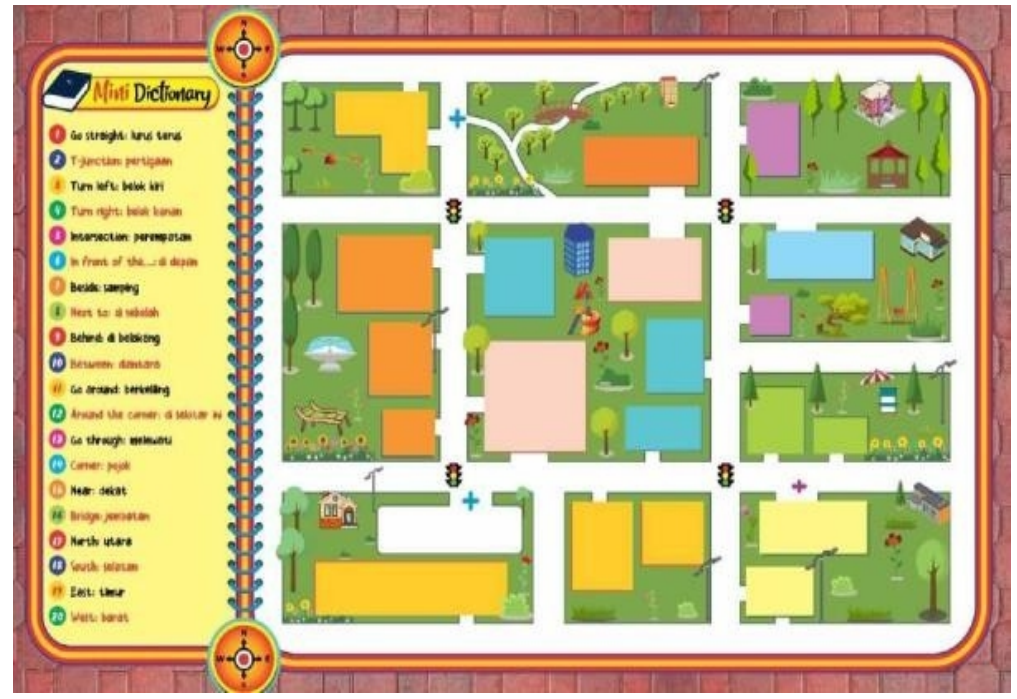

In the first class, 15 students were included in the control group and followed the learning process using the conventional face-to-face method without the help of teaching aid media, only by using handbook material with the theme Getting Direction which was applied using 
conversation gambit in the verbal communication process.

In the second class, 15 students entered the experimental group and followed the learning process using teaching aid media in the form of a Pictorial Metaplan with the theme Getting Direction. Pictorial Metaplan is divided into 3 different city packages, namely: Semarang, London, and New York. The implementation in each of these different cities emphasizes the context of fluency in speaking, vocabulary, and also the process of interaction with two-way verbal communication. The following is a Pictorial Metaplan used to improve students' speaking skills in the experimental group class.

Figure 3

Pictures of Street Names and Building Names that can be Attached to the Pictorial Metaplan and Changed its Position According to The User's Needs.

\begin{tabular}{|c|c|c|c|c|}
\hline & & & $\begin{array}{l}\text { HOSPITAL } \\
\text { FANK }\end{array}$ & 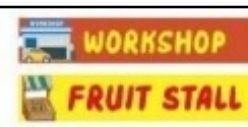 \\
\hline & & & AIRPORT & IEIRAIN STATION \\
\hline $\begin{array}{l}\text { d. Borobudur } \\
\text { dL. Imam Bonjol }\end{array}$ & $\begin{array}{l}\text { Mlettropolitan Avenue } \\
\text { Ridgewood Avenue }\end{array}$ & Abbey road & $\Rightarrow H A R B O U R$ & HE BOOK STORE \\
\hline JI. Dr. Wahidin & Rockquary Boulevarid & Oxford Street & ती MUSEUM & 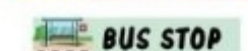 \\
\hline गI. A. Yani & Coss Bay Boulevand & Spring Gardens & III CITY HALL & A. CHURCH \\
\hline ग. Imam Barjo & Atlantic Avenue & Heathfield Road & fLS II CITY PARK & L. MOSQUE \\
\hline JL Prof. Sudarto & logan Street & Westerham Road & 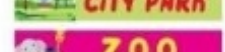 & \\
\hline 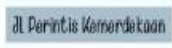 & Liberty Avenue & Warren Road & 200 & III GROCERY STORE \\
\hline ग. Pamularsih & Linden Bculevard & Petts Wood Road & AlD AMUSEMENT PARK & L. UNIUERSITY \\
\hline dL Pemuda & Springfield Beculevard & Cray Ave & ETIF HOTEL & THEATRE \\
\hline dI. Pahlawan & Belmont Park Road & High Street & CAR RENTAL & If SHOPPING maLl \\
\hline d. Diponegoro & Winchester Boulevarit & Sevenoaks Road & \multirow{2}{*}{\multicolumn{2}{|c|}{ i) GAS STATION }} \\
\hline JI. Setiabudi & Langdale Street & Highfield Road & & \\
\hline JI. Durian & lakeville Road & Hookwood Road & \multicolumn{2}{|c|}{ PDOST OFEICE } \\
\hline dI. Ace & New Hyde Park Road & Knockholt road & \multicolumn{2}{|c|}{ EA POLICE STATION } \\
\hline dl. Cemara & Shetter Rock Road & Old London Road & \multicolumn{2}{|c|}{ 醖 $\mathrm{SCHOOL}$} \\
\hline
\end{tabular}

Figure 4

The Implementation of Using Pictorial Metaplan in 8th Grade Junior High School Students to Improve the Speaking Skill

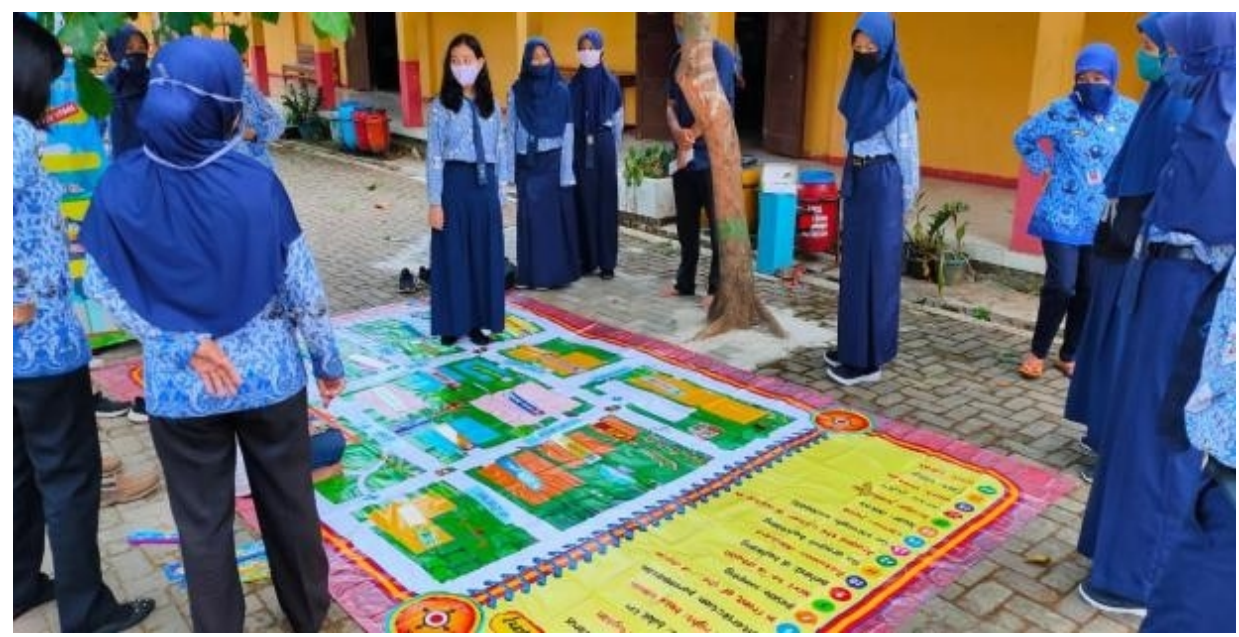




\section{Post-Test Stage}

This stage is the test stage to find out whether there is a significant value from the implementation of the Pre-Test, namely before being given treatment and after being given treatment. The research subjects carried out the Post-Test with the question material, namely the pictorial map as given during the Pre-Test.

Stage of Assessment and Collection of Post- Test Results

Table 1

Paired Sample Statistics Group I

\begin{tabular}{|c|c|c|c|c|c|}
\hline \multicolumn{6}{|c|}{ Paired Samples Statistics } \\
\hline & & Mean & $\mathrm{N}$ & Std. Deviation & $\begin{array}{c}\text { Std. Mean } \\
\text { Error }\end{array}$ \\
\hline \multirow[t]{2}{*}{ Pair 1} & Pretest_1 & 59.40 & 15 & 6,468 & 1,670 \\
\hline & Posttest_1 & 79.47 & 15 & 5,462 & 1,410 \\
\hline
\end{tabular}

Based on Paired Sample Statistics group I, it can be seen that the results of learning outcomes in group I increased from 59.40 to 79.47 , which is an increase of 20.07 points.

The Results of the Control Group Learning

Table 2

Paired Sample Statistics Group II

\begin{tabular}{ll|r|r|r|r} 
& \multicolumn{9}{c}{ Paired Samples Statistics } & \multicolumn{2}{c}{$\begin{array}{c}\text { Std. Mean } \\
\text { Mean }\end{array}$} & N & Std. Deviation & \multicolumn{1}{c}{ Error } \\
\hline Pair 1 & Pretest_2 & 59.40 & 15 & 8,441 & 2,180 \\
\cline { 2 - 7 } & Posttest_2 & 71.87 & 15 & 5,730 & 1,480 \\
\hline
\end{tabular}

The table shows that there is an increase in the learning outcomes of Group II by 12.47 points from the Pre-Test which amounted to 59.40 to the PostTest results of 71.87 .

The Difference In The Learning Outcomes Of The Experimental Group And The Control

\section{Outcomes} below.

\section{Group}

This stage is the final stage of conducting the research, namely by collecting the results of the Pre-Test and Post-Test to be processed using statistical calculations.

\section{The Results of the Experimental Group Learning Outcomes}

The mean result of the Pre-Test group I was 59.40 while the Post-Test result of that group was 79.47. The results of Group 1 Pre-Test and PostTest can be seen in the following table.

The Pre-Test mean result of group II was 59.40, while the Post-Test of that group reached a mean value of 71.87 . This can be seen from the table

The learning outcomes in group I experienced an increase in learning outcomes by 20.07 points, while the learning outcomes in group 2 increased by 12.47 points. The significance of these differences can be seen through the following Independent Sample Test 
Table 3

Independent Samples Test Result

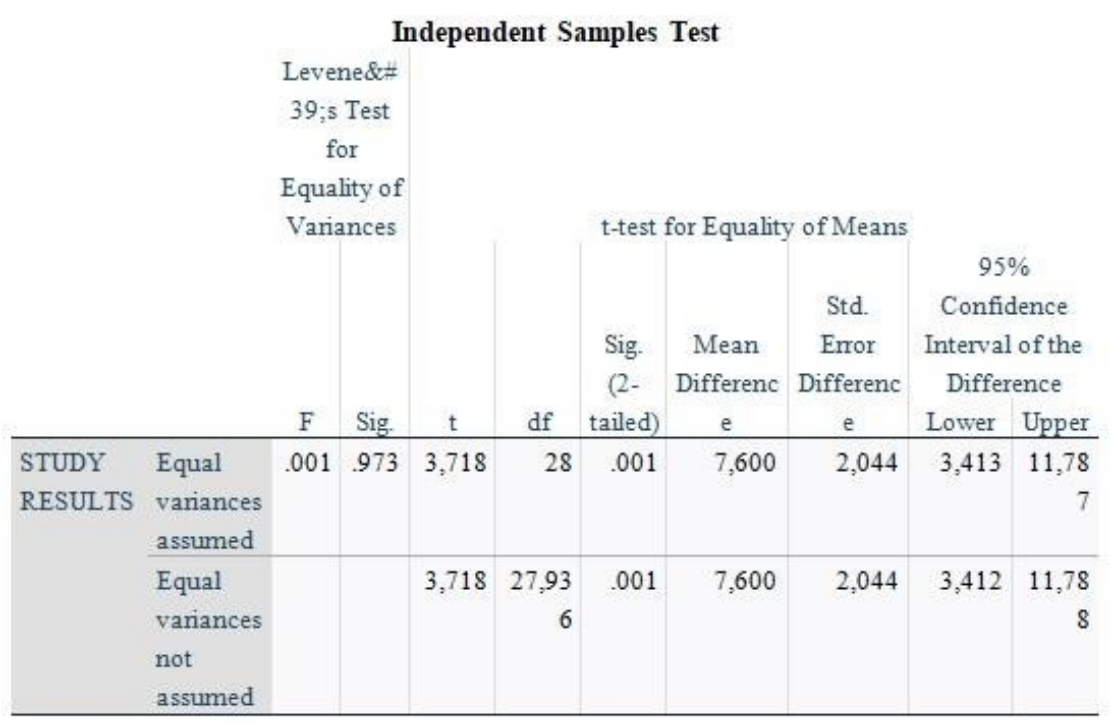

Based on the results of data analysis in Table 4 , it can be seen that the Sig. (2-tailed) value is 0.001 which means less than 0.05 . This shows that $\mathrm{H} 0$ is rejected and $\mathrm{H}$ a is accepted. Thus it can be concluded that learning in the experimental group using Pictorial Metaplan is more effective than learning using conventional methods.

\section{CONCLUSION}

This research fulfills the needs of students to get greater opportunities to do direct practice in learning English. The use of the Pictorial Metaplan media with the theme Getting Direction combined with the Total Physical Response (TPR) method has been able to facilitate students to be more active and creative. Based on the results, it can be concluded that interactive learning using the Pictorial Metaplan as a teaching aid is more effective in improving students' speaking skills, especially on the theme of Getting Direction.

\section{ACKNOWLEDGEMENT}

This research is fully funded by the Direktorat Riset dan Pengabdian Masyarakat Direktorat Jenderal Riset dan Pengembangan Kementerian Riset, Teknologi, dan Pendidikan Tinggi (Indonesian Ministry of Research, Technology, and
Higher Education), therefore we solemnly express our gratitude to the aforementioned institution. We also wanted to express our gratitude to media experts, teachers, and students, who have helped us by giving valuable information to develop our final product.

\section{REFERENCES}

Anggani, D., \& Bharati, L. (2010). Teachers' professional development through an observation in immersion classes based on the documents and teaching and learning processes. Language Circle: Journal of Language and Literature, 4(2), 91101.https://doi.org/10.15294/lc.v4i2.897

Asemota, H. E. (2015). The role of media in English language development. International Journal of Humanities and Social Science Studies (IJHSSS).

Clapper, T. C. (2010). Role play and simulation: Returning to teaching for understanding. Education Digest: Essential Readings Condensed for Quick Review, 75(8), 39-43

Croasdell, D. T., Freeman, L. A., \& Urbaczewski, A. (2003). Concept maps for teaching and assessment. Communications of the Association 
for Information Systems.

https://doi.org/10.17705/1cais.01224

Derakhshan, A., Khalili, A. N., \& Beheshti, F. (2016). Developing EFL Learner's speaking ability, accuracy and fluency. English Language and Literature Studies. https://doi.org/10.5539/ells.v6n2p177

Hapsari, A. G. S. (2020). Investigating non-formal efl teachers' wellbeing in an English Course in Yogyakarta, Indonesia. Language Circle: Journal of Language and Literature, 14(2), 168175. https://doi.org/10.15294/lc.v14i2.22828

Khan, N., \& Ali, A. (2010). Improving the speaking ability in English: The students' perspective. Procedia - Social and Behavioral Sciences. https://doi.org/10.1016/j.sbspro.2010.03. 554

Liu, F., \& Ding, Y. (2009). Role-play in English Language Teaching. Asian Social Science, 5(10), https://doi.org/10.5539/ass.v5n10p140

Maciejewski, M. L. (2020). Quasi-experimental design. Biostatistics and Epidemiology. https://doi.org/10.1080/24709360.2018.1 477468

Maisiska, L. (2014). Using the Metaplan Technique in teaching writing a discussion text to senior high school students. Journal of English Language Teaching. https://doi.org/10.24036/jelt.v2i2.3714

Ovchinnikova, O. M., Frantsuzskaya, E. O., \& Lutoshkina, O. S. (2015). Metaplan-based development of speaking skills. Procedia Social and Behavioral Sciences. https://doi.org/10.1016/j.sbspro.2015.08. 049

Putri, A. R. (2016). Teaching English for Young Learners Using a Total Physical Response (Tpr) Method. Jurnal Edulingua, 3(2).

Ramshaw, L. A. (1989). A metaplan model for problem-solving discourse. https://doi.org/10.3115/976815.976820

Sano, M. (1986). How to incorporate total physical response into the English programme. ELT Journal. https://doi.org/10.1093/elt/40.4.270

Uysal, N. D., \& Yavuz, F. (2015). Teaching English to very young learners. Procedia - Social and Behavioral Sciences. https://doi.org/10.1016/j.sbspro.2015.07. 042

Wu, W., \& Little, T. D. (2011). Quantitative research methods. In Encyclopedia of Adolescence. https://doi.org/10.1016/B978-012- 373951-3.00034-X 
